\title{
APPLICATION OF WELDS ON THE HIGH-CARBON STEEL RAILS
}

\author{
${ }^{1}$ Michal BUČKO, 'Vladimíra SCHINDLEROVÁ, 'ucie KREJČí, ${ }^{1}$ Petr HLAVATÝ, ${ }^{2}$ Jiří HLAVATÝ \\ ${ }^{1}$ VSB - Technical University of Ostrava, Ostrava, Czech Republic, EU, \\ michal.bucko@vsb.cz \\ ${ }^{2}$ Road and Motorway Directorate of the Czech Republic, Prague, Czech Republic, EU, \\ iiri.hlavaty@rsd.cz
}

https://doi.org/10.37904/metal.2019.886

\begin{abstract}
This paper deals with welding on high-carbon steel that is used for the production of tram and railway tracks. The high-quality and efficient maintenance of the track superstructure, especially the refurbishing of worn rails, is an integral part of the operation of rail transport. The rails are subjected to wear and tear and their overall replacement is wasteful and time-consuming, too. Therefore, refurbishing technologies are used that enable us to extend the lifetime of parts applied in technical practice. During the actual operation, the rails are worn out considerably in exposed places, such as the tramway curves in city transport or railway turnouts and frogs of both tram and railway lines. When welding the rails, the aim is to achieve better wear resistance and, at the same time, to comply with all conditions and regulations for rail transport.

This article presents new findings concerning the application of an interlayer with additional material that is different from the additional weld deposit material itself. Furthermore, it deals with the study of transition areas and their influence on the structure in the areas of weld metal, the interlayer, the heat affected zone and base material and mapping the influence on hardness and microhardness. Welding on worn rails using suitable technology can guarantee the unlimited repeatability of welding on further worn weld deposits. The paper evaluates the weld deposits with various additional materials under different welding conditions with the aim of improving the quality of rail refurbishing.
\end{abstract}

Keywords: High-carbon steel, weld deposits, additional material, refurbishing, lifetime

\section{INTRODUCTION}

Rail transport is one of the most important modern transport methods, which is developing in the direction of higher speeds and loads. The state of the rails is a key factor influencing rail transport in terms of safety, infrastructure availability and the total cost of maintenance and restoration of rails. [1,2] Therefore, any reduction in such expenditure would have a significant impact on the current state. To minimize costs, renovation technologies can be used, which belong to the ways of prolonging the durability of stressed parts. $[3,4]$ With the rapid development of high-speed and heavy-duty trains, rail defects are becoming more frequent. Thus, it is very important to increase the durability of the rail surface and extend its life. [5]

When welding materials, the basic condition is to achieve the required quality of the weld, provided that a suitable heat affected zone is achieved. It is necessary that the applied weld deposit does not have any unacceptable defects and at the same time, the weld must meet the requirements for a defined life. $[4,6]$

\subsection{Rail welding technology}

At present, various additional materials are used for weld deposits, which can provide the required properties of the weld layers (Figure 1). In the case of using weld deposits with similar chemical compositions, a deposit with the same or similar characteristics is created. There are also other ways to weld deposits on extremely stressed areas to prolong their lifespan. [7] When using additional material with a different chemical 
composition, problems can arise in the welded metal, in the basic material and especially in heat affected zone. $[6,7]$

For the welding of rails, technology 111, 114, 121, 135 and 136 are used. In most cases, such welding takes place in outdoor areas or in halls (Figure 2). The condition for selecting an appropriate technology is the amount of applied heat, which influences the speed at which the deposit and its surroundings cool down. [8]

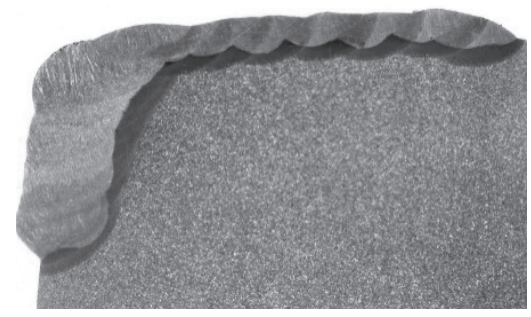

Figure 1 Weld deposit on a rail [4]

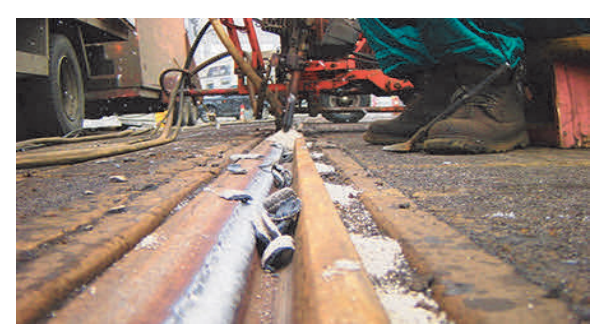

Figure 2 Welding with a machine under flux (121) [8]

The aim of the welding is to:

- $\quad$ Restore worn parts, the weld deposit must have the same or higher mechanical properties than the base material,

- $\quad$ Create a surface layer resistant to abrasive and adhesive wear, etc. [9]

\section{SELECTING MATERIALS FOR TEST WELD DEPOSITS}

For the production of rails, the materials specified in standard ČSN EN 13674-1+A1 are used, which complies with the International standard UIC 860. This standard introduces the most basic types of rail steels used. In the paper, marking according to the standard UIC 860 is used. [8]

\subsection{Basic material}

As a base material, a material marked UIC 900 A was used. Chemical composition (Table 1) and mechanical properties (Table 2) for the selected base material are listed below. [8]

Table 1 Chemical composition of the basic material UIC $900 \mathrm{~A}$

\begin{tabular}{|c|c|c|c|c|c|c|c|c|c|c|c|}
\hline \multirow{2}{*}{ Steel } & \multicolumn{10}{|c|}{ Chemical composition (hm. \%) } \\
\cline { 2 - 13 } & $\mathbf{C}$ & $\mathbf{S i}$ & $\mathbf{M n}$ & $\mathbf{S}$ & $\mathbf{P}$ & $\mathbf{C r}$ & $\mathbf{A l}$ & $\mathbf{N}$ & $\mathbf{V}$ & $\mathbf{N i}$ & $\mathbf{M o}$ \\
\hline \multirow{2}{*}{ UIC 900 A } & 0.62 & 0.15 & 0.7 & 0.008 & max. & max. & max. & max. & max. & max. & max. \\
& 0.8 & 0.58 & 1.2 & 0.025 & 0.025 & 0.15 & 0.004 & 0.009 & 0.03 & 0.1 & 0.02 \\
\hline
\end{tabular}

Table 2 Mechanical properties of the base material UIC $900 \mathrm{~A}$

\begin{tabular}{|c|c|c|c|}
\hline Steel & $\begin{array}{c}\text { Hardness } \\
\text { (HB) }\end{array}$ & $\begin{array}{c}\text { Ductility } \\
(\%)\end{array}$ & $\begin{array}{c}\text { Strength } \\
\text { (MPa) }\end{array}$ \\
\hline UIC 900 A & $260-300$ & Min. 10 & Min. 880 \\
\hline
\end{tabular}

\subsection{Additional materials for the deposit welding of samples}

For the samples, welding machine technology under Flux 121 (SAW) was selected, suitable for the welding of rails, with which the required heat can be applied. For this method and type of weld deposit, the interlayer wire OK AUTROD 13.27 was used together with OK FLUX 10.71, Wegusta wire 1.4370 in combination with OK FLUX 10.93, and Castolin 3205 wire with FLUX 3205. The chemical composition of the additional 
materials for the welding are listed below (Table 3), and additional materials that were used (for the interlayer and weld deposit) in all samples N1-N5 (Table 4). [8,9]

Table 3 Chemical composition of additional materials

\begin{tabular}{|c|c|c|c|c|c|c|c|c|c|}
\hline \multirow{2}{*}{ Additional material } & \multicolumn{9}{|c|}{ Chemical composition (hm. \%) } \\
\cline { 2 - 19 } & $\mathbf{C}$ & $\mathbf{S i}$ & $\mathbf{M n}$ & $\mathbf{S}$ & $\mathbf{P}$ & $\mathbf{C r}$ & $\mathbf{C u}$ & $\mathbf{N i}$ & $\mathbf{M o}$ \\
\hline OK AUTROD 13.27 + OK FLUX 10.71 & 0.06 & 0.32 & 1.26 & 0.01 & 0.019 & 0.08 & 0.08 & 2.35 & 0.02 \\
\hline Wegusta 1.4370 + OK FLUX 10.93 & 0.11 & 0.22 & 6.12 & - & - & 18.24 & - & 9.30 & - \\
\hline Castolin 3205 + FLUX 3205 & 0.3 & 0.55 & 14.00 & - & - & 16.00 & - & 1.70 & - \\
\hline
\end{tabular}

Table 4 Additional materials used for test samples N1-N5

\begin{tabular}{|c|c|c|}
\hline Sample & Additional material for the interlayer & Additional material for the weld deposit \\
\hline N1 & - & Wegusta 1.4370 + OK FLUX 10.93 \\
\hline N2, N3, N5 & OK AUTROD 13.27 + OK FLUX 10.71 & Wegusta 1.4370 + OK FLUX 10.93 \\
\hline N4 & - & Castolin 3205 + FLUX 3205 \\
\hline
\end{tabular}

\section{THE TESTS OF WELD DEPOSITS}

Defined types of weld deposits (samples N1-N5) with different additional materials are listed in Table 5. All welds were applied without preheating. The welding parameters can be found in Table 6 .

Table 5 Macrostructure and characteristics of weld deposit sample N1-N5 [8]

\begin{tabular}{|c|c|}
\hline & Sample N1 \\
\hline & $\begin{array}{l}\text { A single layer weld deposit of the rail top surface. Additional material used was } \\
\text { a Wegusta } 1.4370 \text { wire, with a diameter of } 2.4 \mathrm{~mm} \text { combined with OK FLUX } 10.93 \text {. }\end{array}$ \\
\hline & Sample N2 \\
\hline & $\begin{array}{l}\text { A multilayer side weld deposit on a base material with an interpass temperature } \\
\text { of } 180{ }^{\circ} \mathrm{C} \text {. Two types of additional material were used, the first foundation layer was } \\
\text { welded with an OK AUTROD } 13.27 \text { wire of } 2.4 \mathrm{~mm} \text { diameter, using OK FLUX } 10.71 \text { and } \\
\text { other layers with a Wegusta } 1.4370 \text { double wire, with a diameter of } 2.4 \mathrm{~mm} \text { combined } \\
\text { with OK FLUX } 10.93 \text {. }\end{array}$ \\
\hline \multirow{4}{*}{$\begin{array}{l}\text { layer } \\
\text { no. } \\
\text { no. } 4 \\
\text { layer } \\
\text { no. } 1-3\end{array}$} & Sample N3 \\
\hline & $\begin{array}{l}\text { A multilayer side weld on a base material with an interpass temperature of } 180^{\circ} \mathrm{C} \text {. } \\
\text { Additional material for the first foundation layer was an OK AUTROD } 13.27 \text { wire with } \\
\text { a diameter of } 2.4 \mathrm{~mm} \text { combined with OK FLUX 10.71. Other layers were made with } \\
\text { Wegusta } 1.4370,2.4 \mathrm{~mm} \text { diameter, combined with OK FLUX } 10.93 \text {. }\end{array}$ \\
\hline & Sample N4 \\
\hline & $\begin{array}{l}\text { A multilayer side weld on a base material with an interpass temperature of } 180^{\circ} \mathrm{C} \text {. As } \\
\text { the additional material, Castolin } 3205 \text { wire was used, with a diameter of } 2.8 \mathrm{~mm} \\
\text { combined with Castolin FLUX } 3205 \text {. }\end{array}$ \\
\hline \multirow{2}{*}{$\begin{array}{ll}\text { layer } & \text { layer } \\
\text { no. 2-6 no. } 1\end{array}$} & Sample N5 \\
\hline & $\begin{array}{l}\text { A multilayer side weld on a base material with an interpass temperature of } 180{ }^{\circ} \mathrm{C} \text {. } \\
\text { Additional material for the first upper foundation layer was OK AUTROD } 13.27 \text { wire, } \\
\text { with a diameter } 2.4 \mathrm{~mm} \text { combined with OK FLUX } 10.71 \text {. Other layers were welded using } \\
\text { a Wegusta } 1.4370 \text { wire with a diameter of } 2.4 \mathrm{~mm} \text { and OK FLUX } 10.93 \text {. }\end{array}$ \\
\hline
\end{tabular}


Five test weld deposits with different additional materials were applied under various welding conditions. As a base material, UIC 900 A was used. the welding was carried out by 121 technology - Automatic machine under flux (SAW).

Table 6 Parameters for welding samples N1-N5

\begin{tabular}{|c|c|c|c|c|c|c|}
\hline Sample & Layer & $\begin{array}{c}\text { Base } \\
\text { material }\end{array}$ & $\begin{array}{l}\text { Current } \\
\text { (A) }\end{array}$ & $\begin{array}{l}\text { Voltage } \\
\text { (V) }\end{array}$ & $\begin{array}{c}\text { Weld } \\
\text { speed(cm•min } \\
\text { 1) }\end{array}$ & $\begin{array}{c}\text { Interpass } \\
\text { temperature } \\
\left(\mathbf{k J} \cdot \mathrm{cm}^{-1}\right)\end{array}$ \\
\hline N1 & 1 & UIC $900 \mathrm{~A}$ & 350 & 31 & 60 & 10.31 \\
\hline \multirow{2}{*}{ N2 } & 1 & UIC $900 \mathrm{~A}$ & 300 & 26 & 60 & 7.41 \\
\hline & $2-5$ & UIC $900 \mathrm{~A}$ & 450 & 38 & 33 & 29.54 \\
\hline \multirow{3}{*}{ N3 } & $1-3$ & UIC $900 \mathrm{~A}$ & 270 & 60 & 60 & 7.7 \\
\hline & 4 & UIC $900 \mathrm{~A}$ & 270 & 60 & 60 & 7.7 \\
\hline & $5-12$ & UIC $900 \mathrm{~A}$ & 350 & 31 & 60 & 10.93 \\
\hline N4 & 1 & UIC $900 \mathrm{~A}$ & 320 & 32 & 30 & 19.46 \\
\hline \multirow{2}{*}{ N5 } & 1 & UIC $900 \mathrm{~A}$ & 300 & 26 & 60 & 7.41 \\
\hline & $2-6$ & UIC $900 \mathrm{~A}$ & 300 & 30 & 60 & 8.55 \\
\hline
\end{tabular}

\section{EVALUATION OF THE RESULTING WELDS ON SURFACE TO REFURBISH RAILS}

A metallographic evaluation for the assessment of macrostructure and microstructure was performed for all samples N1-N5 to evaluate the resulting weld deposits. In addition, a hardness measurement HV10 and microhardness HV0.1 according to Vickers was performed on all samples. All measurements are shown in the sample N5.

\subsection{Metallographic evaluation of samples}

For the determination of basic material structures and weld deposits an etcher for austenite was applied and perlitic material according to Adler-Matting $+10 \% \mathrm{HNO}_{3}$ (nitric acid), electrical etching was also used with $4 \% \mathrm{H}_{2} \mathrm{CrO}_{4}$ (chromic acid) $+4 \% \mathrm{HNO}_{3}$. The etching parameters were $5 \mathrm{~V}$ and $2 \mathrm{~A}$ for the 30 s. The microstructure of the weld deposit melting edge and the interlayer, together with the detail of the interlayer area and the base material for the N5 sample is shown below (Figure 3) and in detail (Figure 4). [8]

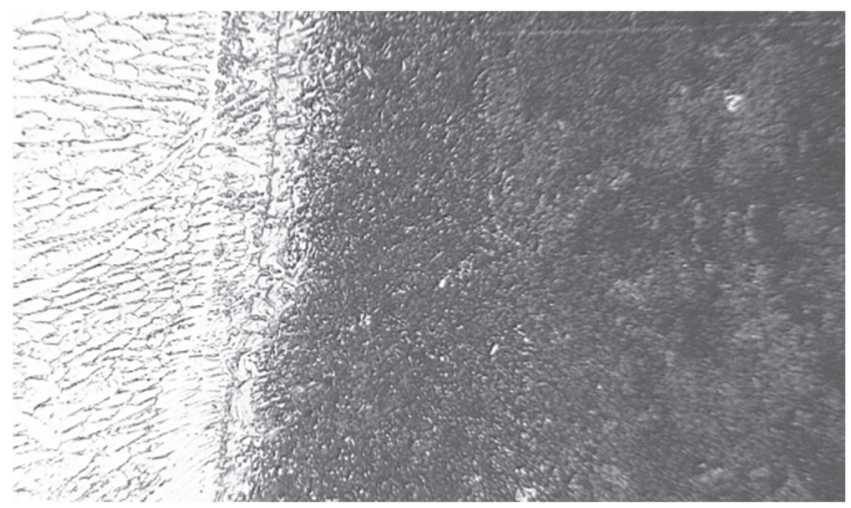

Figure 3 Area of the melted weld and interlayer [8]

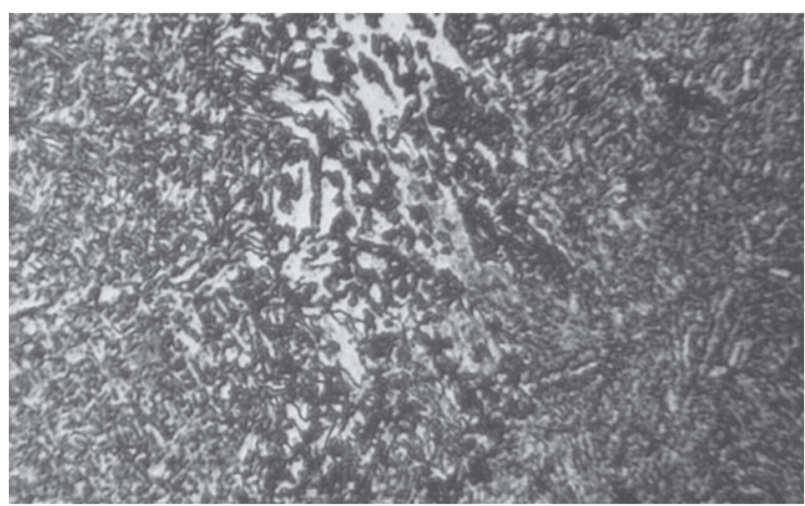

Figure 4 Detail of the melting area and interlayer N5 [8] 


\subsection{Measuring hardness and microhardness of selected areas by Vickers}

Measurements were carried out in the areas of the weld metal over the heat affected zone (HAZ), up to the base material. The maximum permissible hardness value was set at $420 \mathrm{HV} 10$ according to regulations: "Welding of railway vehicles for Czech Railways ČD V 95/5" and "Czech Railways regulation for welding and welded deposits on the upper track surfaces ČD V 3/5". [10,11]

The resulting hardness values HV10 for the sample N5 are listed in the table below (Table 7). Based on the results of hardness measurement HV10 (Figure 5) and on the microstructure documentation the following areas were assessed (HAZ for the base material, HAZ of the interlayer, the interlayer, weld deposit metal and the base material) to measure the hardness HV0.1. The distance between individual imprints was determined to $300 \mu \mathrm{m}$ (Figure 6).

Table 7 Hardness measurement results of HV10 in the weld of the sample N5 [8]

\begin{tabular}{|c|c|c|c|c|c|c|c|c|c|c|c|c|c|c|}
\hline \multirow{4}{*}{$\begin{array}{c}\text { Sample } \\
\text { N5 }\end{array}$} & Measurement & 1 & 2 & 3 & 4 & 5 & 6 & 7 & 8 & 9 & 10 & 11 & 12 & 13 \\
\cline { 2 - 12 } & HV10 & 351 & 348 & 345 & 405 & 413 & 402 & 383 & 380 & 351 & 274 & 254 & 253 & 274 \\
\cline { 2 - 11 } & Area & \multicolumn{3}{|c|}{ Weld } \\
\hline
\end{tabular}

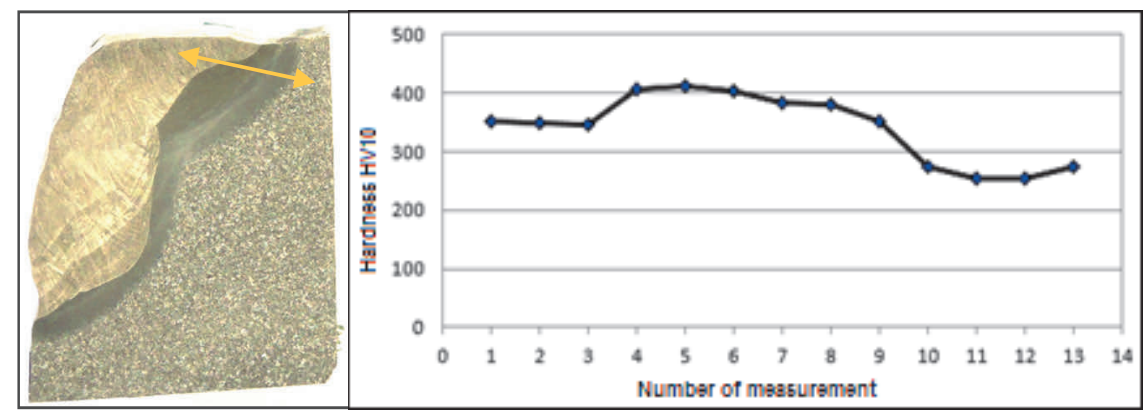

Figure 5 Hardness measurement HV10 for the weld deposit N5 [8]

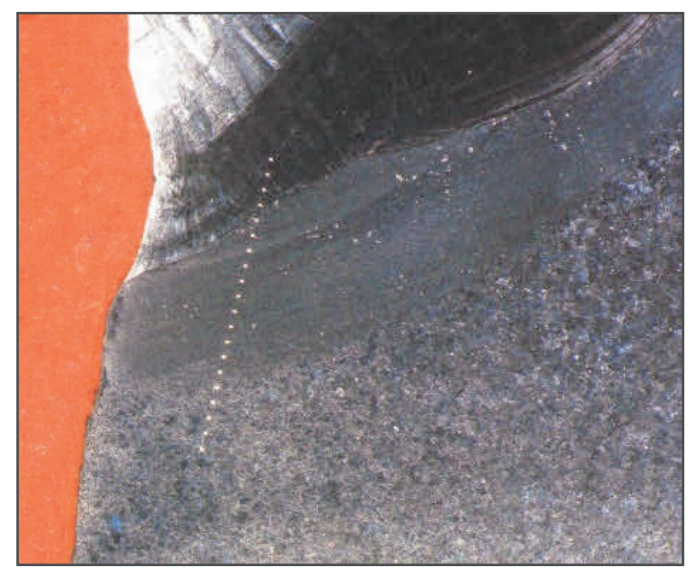

Figure 6 Line of imprints HV0.1 N5 [8]

Microhardness measurement HV0.1 was done in three lines. For the sample N5, it can be stated that, for the first line of the interlayer and the base material, the microhardness values in the area ranged from 389 to 406. The maximum measured value of microhardness in HAZ was 415 and the value of the base material ranged from 245 to 281 . For the second line of measurement, the values in the area of the weld ranged between 380-411 and the maximum value of microhardness measured in TOO was 408 . Values for the basic material were 246-280. The third line measurement and its values are shown below (Table 8 and Figure 7). 
Table 8 Microhardness measurement results HV0.1 for the sample N5 and line No. 3: weld-interlayer [8]

\begin{tabular}{|c|c|c|c|c|c|c|c|c|c|c|c|c|}
\hline \multirow{3}{*}{$\begin{array}{c}\text { Sample } \\
\text { N5 line } \\
\text { No. } 3\end{array}$} & Measurement & -1.5 & -1.2 & -0.9 & -0.6 & -0.3 & 0 & 0.3 & 0.6 & 0.9 & 1.2 & 1.5 \\
\hline & HV0.1 & 354 & 366 & 355 & 364 & 402 & 414 & 376 & 398 & 405 & 386 & 395 \\
\hline & Area & \multicolumn{5}{|c|}{ Weld deposit } & Melting edge & \multicolumn{5}{|c|}{ Interlayer } \\
\hline
\end{tabular}

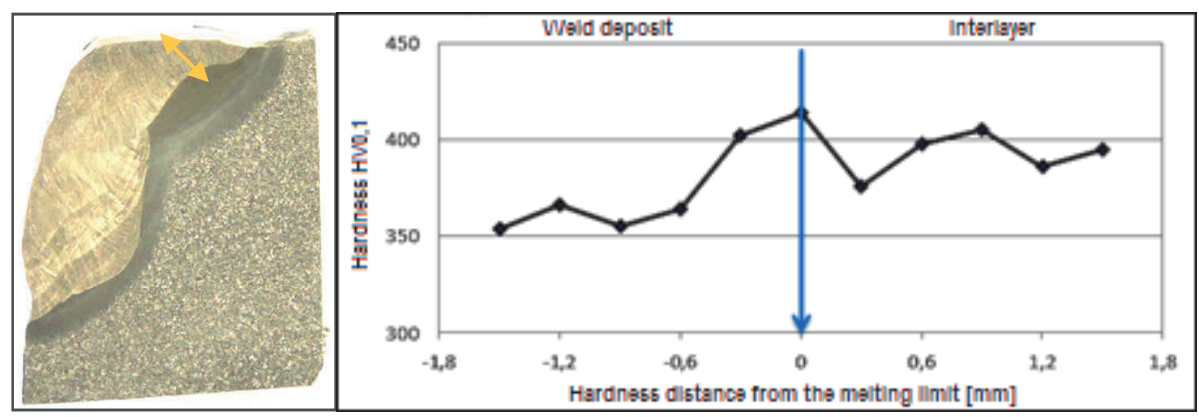

Figure 7 Microhardness measurement HV0.1, line no. 3: weld-interlayer of the N5 sample [8]

\subsection{Evaluation of weld deposits N1-N5 to refurbish the rails}

Based on the measurements, samples N1-N4 were evaluated as unsatisfactory. Hardness values exceeded the maximum defined value $420 \mathrm{HV} 10$ in certain areas, and therefore, samples N1-N4 can be marked as unsatisfactory $[8,11,12]$. In the above-mentioned weld deposits, there were also unacceptable defects such as cracks and pores. The metallographic evaluation revealed the development of undesirable structures showing turbidity. As a measure to prevent the emergence of unacceptable structures, an increase in the value of the interpassing heat can be suggested, by adjusting the conditions for the welding. This can be achieved e.g. by decreasing the welding speed or by increasing the welding current and voltage values. For sample N5, the maximum permissible value was not exceeded in the hardness measurement. The metallographic evaluation did not reveal defects or undesirable turbidity structures. In the area of the interlayer, there was no decrease in hardness or defects. Thus, the sample N5 meets the requirements for the instructions according to the regulations. [4,6]

Based on the evaluation of all the welds performed on samples N1-N5 it was proved that the only weld deposit suitable for rail refurbishment, in accordance with the regulations, is the N5 sample.

\section{CONCLUSION}

This paper deals with the renovation of the base material UIC $900 \mathrm{~A}$ used for the upper surface of rails, which is provided using suitable additional materials and their combinations when laying the individual layers of the weld deposits. To carry out the sample tests properly, it was first necessary to identify the basic and additional materials. A metallographic analysis was carried out on the prepared samples in the areas of the weld, the interlayer, the heat affected zone (HAZ) and the basic material. The hardness measurement HV10 was also performed on the samples and in selected areas of microhardness measurement HV0.1, according to the regulation by the Czech Railways.

The N1-N4 samples were found to be unsatisfactory in terms of the hardness readings, which were impermissible for these weld deposits. Furthermore, these samples also showed defects and unacceptable turbidity. The sample N5 can be used as the only suitable one, where no defects or improper structures were found. Also, the hardness values HV10 and HV0.1 did not exceed the highest set values $420 \mathrm{HV} 10$. The results are used in the welding of the upper track surface in the tramway and are used for further research. 


\section{REFERENCES}

[1] GAO, B., TAN, Z., LIU, Z., GAO, G., ZHANG, M., ZHANG, G., BAI, B. (2019). Influence of non-uniform microstructure on rolling contact fatigue behavior of high-speed wheel steels. Engineering Failure Analysis, Vol. 100, 2019, pp. 485-491, ISSN 13506307.

[2] JOVANOVIĆ, S., GULER, H., ČOKO, B. (2015). Track degradation analysis in the scope of railway infrastructure maintenance management systems. Gradjevinar, Vol. 67 (3), 2015, pp. 247-258, ISSN 03502465.

[3] JOVANOVIĆ, S., BOŽOVIĆ, D., TOMIČIĆ-TORLAKOVIĆ, M. (2014). Railway infrastructure condition-monitoring and analysis as a basis for maintenance management. Gradjevinar, Vol. 66 (4), pp. 347-358, ISSN 03502465.

[4] KREJČí, L., SCHINDLEROVÁ, V., BUČKO, M., HLAVATÝ, I. Application of a process FMEA for the welding. In METAL 2018: 27th International Conference on Metallurgy and Materials. Ostrava: TANGER, 2018, pp. 1145-1151, ISBN 978-80-87294-84-0.

[5] MENG, L., ZHAO, W., HOU, K., KOU, D., YUAN, Z., ZHANG, X., XU, J., HU, Q., WANG, D., ZENG, X. (2019). A comparison of microstructure and mechanical properties of laser cladding and laser-induction hybrid cladding coatings on full-scale rail. Materials Science and Engineering A, Vol.748, 2019, pp. 1-15, ISSN 09215093.

[6] MASOUMI, M., ARIZA, E.A., SINATORA, A., GOLDENSTEIN, H. (2018). Role of crystallographic orientation and grain boundaries in fatigue crack propagation in used pearlitic rail steel. Materials Science and Engineering A, Vol. 722, 2018, pp. 147-155, ISSN 09215093.

[7] HLAVATÝ, I., KOZÁK, J., KREJČí, L., SAMARDŽIĆ, I., TUOMINEN, J. The Effect of Tungsten Carbide Particles Content in a Weld Deposit on its Abrasion Resistance. TEHNICKI VJESNIK-TECHNICAL GAZETTE, Vol. 2017, 24, No. 5, pp. 1345-1349, ISSN 1330-3651 (Print), ISSN 1848-6339 (Online).

[8] HLAVATÝ, P. Implementation of Overlay on High-Carbon Steel: Master Thesis. Ostrava: VŠB - Technical University of Ostrava, Faculty of Mechanical Engineering, Department of Mechanical Technology. 2015, 68 p.

[9] NAGENTRAU, M., TOBI, A.L.M., SAMBU, M., JAMIAN, S. (2019) The influence of welding condition on the microstructure of WC hardfacing coating on carbon steel substrate. International Journal of Refractory Metals and Hard Materials, Vol. 82, 2019, pp. 43-57, ISSN 02634368.

[10] Č́D V 95/5. Czech Railways regulation for welding of railway vehicles. Praha, 1999.

[11] Č́D S 3/5. Czech Railways regulation for welding and welded deposits on the upper track surfaces. Praha. 2003. 